\title{
Heavy Metals in the Environment
}

\section{A Laboratory Study of Bacteria-Facilitated Cadmium Transport in Alluvial Gravel Aquifer Media}

\author{
L. Pang,* M. E. Close, M. J. Noonan, M. J. Flintoft, and P. van den Brink
}

\begin{abstract}
Colloids, including bacteria, can dramatically accelerate the transport of heavy metals in ground water. Batch and column experiments were conducted to investigate adsorption of cadmium (Cd) onto Bacillus subtilis spores or Escherichia coli vegetative cells and Cd transport in alluvial gravel aquifer media in the presence of these bacteria. Results of the batch experiments showed that adsorption of $\mathrm{Cd}$ onto the bacteria was (i) positively related to solution $\mathrm{pH}$, bacterial concentration, and negative surface charge, but inversely related to $\mathrm{Cd}$ concentration and (ii) a rate-limited nonlinear process, but adsorption onto E. coli was much less. For column influent $C d$ concentrations of about $4 \mathrm{mg} / \mathrm{L}$ and bacterial concentrations of $\geq 10^{5}$ colony-forming units (cfu) $/ \mathrm{mL}$, there was a significant increase in total $\mathrm{Cd}$ effluent concentrations. In comparison with controls that did not have bacteria-facilitated transport, Cd traveled 17 to 20 times faster when it traveled with mobile bacteria. However, Cd traveled mostly 2 to 3 times slower during the desorption phase under the influence of bacteria retained in the column. The difference between total and dissolved $\mathrm{Cd}$ concentrations was significant during $\mathrm{Cd}$ cotransport with $\mathrm{B}$. subtilis spores, but this concentration difference was very small during $\mathrm{Cd}$ cotransport with $E$. coli, suggesting an adsorption-dominant mechanism during Cd cotransport with the spores and the possibility of $\mathrm{Cd}$ chelation by the dissolved membrane vesicles secreted from $E$. coli cell walls. Bacteria-facilitated transport of heavy metals may pose a threat to ground water quality in sites such as landfills and following land disposal of industrial and domestic effluent and sludge.
\end{abstract}

$\mathrm{C}$ OLLoIDs (e.g., microbes, humic substances, clays, and metal oxides) have an affinity for heavy metals because their surfaces are oppositely charged and colloids have high adsorption capacities. Compared with solutes, colloids are large $(0.01-10 \mu \mathrm{m})$ and they can only travel through large interconnected pores because they are filtered out by small pores. Therefore, the transport velocity of heavy metals adsorbed to colloids can either be enhanced or inhibited relative to dissolved metals, depending on the behavior of the colloids to which they are attached (Yee and Fein, 2002). The transport velocity of heavy metals adsorbed onto the mobile colloids can be dramatically accelerated because colloids that travel through highly permeable large pores can travel faster than conservative tracers (Park et al., 1991; Rossi et al., 1994; Artinger et al., 2002). For exam-

L. Pang, M.E. Close, M.J. Flintoft, and P. van den Brink, Institute of Environmental Science \& Research Ltd, PO Box 291 81, Christchurch, New Zealand. M.J. Noonan, Animal and Food Science Division, Lincoln University, PO Box 84, Canterbury, New Zealand. Received 2 Mar. 2004. *Corresponding author (liping.pang@esr.cri.nz).

Published in J. Environ. Qual. 34:237-247 (2005).

(c) ASA, CSSA, SSSA

677 S. Segoe Rd., Madison, WI 53711 USA ple, in the presence of colloids, the transport velocity of copper and zinc increased 5 to 50 times (Karathanasis, 1999), and transport velocity of lead increased 10 to 3000 times, compared with control experiments where no colloids were present (Karathanasis, 2000). Pang and Close (1999a) reported that the transport velocity of a portion of $\mathrm{Cd}$ through an alluvial gravel aquifer in the field was enhanced 5 to 28 times in the presence of bacteria.

Bacteria are important colloids that can affect heavy metal transport in the subsurface environment. Bacterial surfaces are often negatively charged in natural environments (Harden and Harris, 1952), and their surfaces display functional groups that effectively bind dissolved cationic metals (Konhauser et al., 1993; Fein et al., 1997; Fowle and Fein, 1999). Concentrations of bacteria in ground water can be very high, particularly if the aquifer is affected by human activities. For example, bacterial concentrations can be as high as $10^{4} \mathrm{cfu} / \mathrm{mL}$ in ground water that has been contaminated by septic tank effluent (Pang et al., 2003) and on the order of $10^{3} \mathrm{cfu} / \mathrm{mL}$ in landfill leachate (Donnelly et al., 1981). Bacterial concentrations in ground water on the order of $10^{8} \mathrm{cfu} / \mathrm{mL}$ have also been reported (Yee and Fein, 2002). In soil environments, bacterial concentrations are generally higher than in ground water systems, and can be up to $10^{7}$ to $10^{10} \mathrm{cells} / \mathrm{g}$ of solid (Alexander, 1977; Ghiorse and Wilson, 1988).

A number of researchers have recently studied metal adsorption onto bacteria (Daughney and Fein, 1998; Daughney et al., 1998; Fein and Delea, 1999; Fowle and Fein, 2000, 2001; Yee et al., 2000; Martinez and Ferris, 2001; Yee and Fein, 2001, 2002; Fein et al., 2002; Kulczycki et al., 2002). Most of these studies made use of the common soil bacterium, B. subtilis, and one of the most mobile and toxic heavy metals, cadmium (Daughney and Fein, 1998; Daughney et al., 1998; Fein and Delea, 1999; Fowle and Fein, 2000; Martinez and Ferris, 2001; Yee and Fein, 2002; Kulczycki et al., 2002). Fewer studies have investigated $\mathrm{Cd}$ adsorption onto $E$. coli (Yee and Fein 2001; Martinez and Ferris, 2001; Kulczycki et al., 2002). These studies typically used bacterial concentrations of 0.1 to $70 \mathrm{~g}$ dry wt. bacteria/L (about $10^{9}$ to $10^{12} \mathrm{cfu} / \mathrm{mL}$ ), metal concentrations of 1 to $35 \mathrm{mg} / \mathrm{L}\left(10^{-4}\right.$ to $\left.10^{-5} \mathrm{~mol} / \mathrm{L}\right)$, and ionic strengths of 0.01 to $0.1 \mathrm{~mol} / \mathrm{L}$ with a single background electrolyte $\left(\mathrm{NaNO}_{3}, \mathrm{KNO}_{3}\right.$, or $\left.\mathrm{NaClO}_{4}\right)$. These experimental conditions are very different from those of natural ground water systems. Most data are derived from batch studies

Abbreviations: BTC, breakthrough curve; cfu, colony-forming unit; $\mathrm{PV}$, pore volume. 
Table 1. Characteristics of the bacterial cells used in this study.

\begin{tabular}{|c|c|c|c|c|c|c|c|c|}
\hline \multirow[b]{2}{*}{ Bacterial species } & \multicolumn{5}{|c|}{ Information from literature $\dagger$} & \multicolumn{3}{|c|}{ Properties measured in this study } \\
\hline & Gram & Shape & $D \doteqdot$ & $\boldsymbol{L} \ddagger$ & Occurrence & $\boldsymbol{D}$ & $\boldsymbol{L}$ & Zeta potential§ \\
\hline & & & \multicolumn{2}{|c|}{$\longrightarrow \mu \mathbf{m} \longrightarrow$} & & \multicolumn{2}{|c|}{$-\mu \mathbf{m}-$} & \\
\hline Bacillus subtilis vegetative cells & positive & rods & $0.7-0.8$ & 2.0-3.0 & nonmotile, occur singly or in chains & 0.89 & 2.71 & -7.0 \\
\hline B. subtilis endospores & positive & ellipsoidal & 0.8 & $1.5-1.8$ & nonmotile, occur singly & $\mathbf{0 . 8 5}$ & 1.27 & $-\mathbf{3 0 . 0}$ \\
\hline Clostridium perfringens & positive & straight rods & $0.6-2.4$ & $1.3-19.0$ & nonmotile, occur singly or in pairs & 0.84 & 3.34 & -26.9 \\
\hline Escherichia coli & negative & straight rods & 1.1-1.5 & $2.0-6.0$ & occur singly or in pairs & 0.76 & 1.42 & -21.3 \\
\hline Enterobacter aerogenes & negative & straight rods & $0.6-1.0$ & $1.2-3.0$ & motile & 0.26 & 1.33 & -20.7 \\
\hline Salmonella menston & negative & rods & $0.7-1.5$ & $2.0-5.0$ & motile with flagella & 0.57 & 1.22 & -4.7 \\
\hline
\end{tabular}

$\dagger$ Information on B. subtilis spores is from Kinoshita et al. (1993); other data are from Sneath et al. (1986).

$\$$ The term $D$ is diameter and $L$ is length, measured in this study using optical microscopy.

$\S$ Measured using a Zetasizer 3000 in this study at a bacterial concentration of $10^{7}$ to $10^{8}$ colony-forming units $(\mathrm{cfu}) / \mathrm{mL}$ and $\mathrm{pH}=7.5$.

without soil or aquifer materials, although Yee et al. (2000) and Yee and Fein (2002) investigated metal adsorption by bacteria in the presence of quartz sand.

To study bacteria-facilitated metal transport in ground water, realistic values of bacterial concentration, ionic strength, and chemical composition should be considered in the experimental design. As mentioned above, the highest reported bacterial concentration in ground water is $10^{8} \mathrm{cfu} / \mathrm{mL}$. The ionic strength of ground water in New Zealand is usually in a magnitude of $10^{-3} \mathrm{~mol} / \mathrm{L}$, for example, $0.002 \mathrm{~mol} / \mathrm{L}$ in alluvial gravel ground water (Pang and Close, 1999b) and $0.003 \mathrm{~mol} / \mathrm{L}$ in pumice sand ground water (Pang and Close, 2001). Natural ground water contains multiple background electrolytes, and hence competing cations and complexing anions may affect the adsorption of metal onto bacteria. This study attempted to obtain results relevant to the "real" world by using natural ground water, which contains multiple solutes together with an ionic strength and bacterial concentrations that are much lower than those used in the studies reported in the literature. The objectives of this study were to (i) examine the effects of $\mathrm{pH}$, bacterial and Cd concentrations, adsorption time, surface charge, and bacterial size on Cd adsorption on bacteria; and (ii) investigate bacteria-facilitated Cd transport in saturated alluvial gravel aquifer media. The first objective was accomplished through batch experiments in the absence of aquifer material. The second objective was achieved by conducting column experiments with either $B$. subtilis spores or $E$. coli at different influent concentrations of bacteria.

\section{MATERIALS AND METHODS}

\section{Properties of Contaminants, Aquifer Material, and Ground Water}

Bacillus subtilis spores and E. coli vegetative cells were used in the batch and column experiments. Bacillus subtilis is a gram-positive, spore-forming bacterium that is common in subsurface environments. Bacillus subtilis spores are harmless to human health, are similar in size to many bacteria, and undergo little die-off, so they are often used as the model bacteria in field-tracer experiments (Pike et al., 1969; Houston et al., 1989; Pang et al., 1998). Escherichia coli is a gramnegative species of the fecal coliform group that is consistently present in human wastes, and is commonly used as an indicator of fecal contamination. To examine the effects of surface charge and cell size on the adsorption of Cd onto the bacteria, additional species of bacteria were used in the batch tests.
These included Salmonella menston, B. subtilis vegetative cells, Enterobacter aerogenes, and Clostridium perfringens, all of which may be found in landfill leachates (Donnelly et al., 1981). Some characteristics of the bacterial cells used in this study are listed in Table 1. Cadmium is a toxic heavy metal that is a trace ground water constituent and is nonessential to human health. For all of the experiments, cadmium nitrate $\left[\mathrm{Cd}\left(\mathrm{NO}_{3}\right)_{2} \cdot 4 \mathrm{H}_{2} \mathrm{O}\right]$ was used as the source of the metal, which has a solubility of $2150 \mathrm{mg} / \mathrm{L}$.

The aquifer material used in the column experiments was taken from below the water table during well-drilling at Burnham, Canterbury, New Zealand; this was the same field site as that used in the studies of Pang et al. (1998) and Pang and Close (1999a). It has a low cation exchange capacity (0.96 $\left.\mathrm{mmol}_{\mathrm{c}} / 100 \mathrm{~g}\right)$, low organic carbon content $(0.04 \%)$, and very little clay mineral content. The gravel surfaces are often coated with a layer of (predominantly) iron oxides, 6 to $13 \mu \mathrm{m}$ thick. The particle sizes used for the column approximated the actual aquifer medium with a median grain size of D50 $=16.69 \mathrm{~mm}$ and uniformity coefficient of D60/D10 = 53. Tap water (untreated ground water pumped from alluvial gravel aquifers) was used as the background electrolyte for all of the column and batch experiments. This is an $\mathrm{Na}-\mathrm{Ca}-\mathrm{HCO}_{3}$ type of water with an ionic strength of $0.002 \mathrm{~mol} / \mathrm{L}$ and a $\mathrm{pH}$ of 6.5 to 7.8 . The chemical composition of tap water is very similar to that of the ground water at the field site where the aquifer media were taken, as shown in Table 2.

\section{Culture and Assay of the Bacteria}

Bacillus subtilis were grown in NBS medium at $30^{\circ} \mathrm{C}$ for $5 \mathrm{~d}$ according to the method of Houston et al. (1989). The culture was heated to $80^{\circ} \mathrm{C}$ for $10 \mathrm{~min}$ to kill vegetative cells and then held at $-20^{\circ} \mathrm{C}$. The frozen culture was thawed and centrifuged at $5000 \mathrm{rpm}$ for $10 \mathrm{~min}$ and the supernatant discarded. The cells were resuspended in sterile tap water and recentrifuged. This procedure was repeated twice. A suspension of suitable concentration was prepared for application to the batch and column experiments. Bacillus subtilis samples collected from the experiments were frozen. Two days later the samples were thawed and heated to $80^{\circ} \mathrm{C}$ for $10 \mathrm{~min}$. The endospores were enumerated using membrane filtration with the filters being placed on $\mathrm{CHG}$ agar containing $5 \mathrm{mg} / \mathrm{L}$ rifampicin for incubation at $30^{\circ} \mathrm{C}$ for $48 \mathrm{~h}$ (Houston et al., 1989).

The other bacteria species (E. coli, S. menston, B. subtilis vegetative cells, E. aerogenes, and $C$. perfringens) were cultured in BHI broth (Brain Heart Broth, 1.10493; Merck, Darmstadt, Germany). Escherichia coli, B. subtilis vegetative cells, E. aerogenes, and $S$. menston were grown aerobically at $35^{\circ} \mathrm{C}$. Clostridium perfringens cells were grown anaerobically at $35^{\circ} \mathrm{C}$ using the Oxoid AnaeroGen anaerobic system (Oxoid Ltd, Basingstoke, UK). To remove cations and anions from the growth media, these bacterial cells were washed in physiologi- 
Table 2. Chemistry of the tap water used in the column and batch experiments (untreated ground water from alluvial gravel aquifers) and compared with the chemistry of the ground water where the aquifer media were taken.

\begin{tabular}{|c|c|c|}
\hline Parameter & $\begin{array}{l}\text { Tap water } \\
\text { (7 samples) }\end{array}$ & $\begin{array}{l}\text { Ground water } \\
\text { (25 samples) }\end{array}$ \\
\hline pH & $7.2(6.5$ to 7.8$)$ & 6.9 (6.6 to 7.2$)$ \\
\hline $\begin{array}{l}\text { Conductivity, } \\
\mathrm{mS} / \mathrm{m}\end{array}$ & $12.0(9.5$ to 13.6$)$ & $10.6(6.40$ to 15.0$)$ \\
\hline $\begin{array}{l}\text { Ionic strength, } \\
\mathrm{mol} / \mathrm{L}\end{array}$ & $0.0017(0.0013$ to 0.0022$)$ & $0.0017(0.0014$ to 0.0018$)$ \\
\hline $\mathrm{HCO}_{3}$ & $65.3(54$ to 76$)$ & 38 (38 to 38$)$ \\
\hline Cl & $4.9(3.8$ to 6.7$)$ & $3.8(1.5$ to 15.0$)$ \\
\hline $\mathbf{N O}_{2}-\mathbf{N}$ & $<0.002(<0.001$ to $<0.005)$ & $0.001(0.000$ to 0.005$)$ \\
\hline $\mathbf{N O}_{3}-\mathbf{N}$ & $0.91(0.34$ to 1.20$)$ & $1.60(0.20$ to 4.5$)$ \\
\hline $\mathbf{N H}_{3}-\mathbf{N}$ & $<0.02$ ( $<0.01$ to $<0.04)$ & $0.012(0.002$ to 0.058$)$ \\
\hline $\mathrm{SO}_{4}$ & $5.63(4.10$ to 6.80$)$ & $5.35(5.30$ to 5.40$)$ \\
\hline $\mathbf{F}$ & $0.70(<0.20$ to 0.96$)$ & $<0.20(<0.20$ to $<0.20)$ \\
\hline $\mathbf{N a}$ & 7.43 (6.3 to 9.8$)$ & $7.0(4.0$ to 13.0$)$ \\
\hline $\mathbf{K}$ & $0.70(<0.53$ to 1.00$)$ & $0.90(0.50$ to 1.30$)$ \\
\hline $\mathbf{C a}$ & $13.70(8.80$ to 18.70$)$ & 11.0 (11.0 to 12.0) \\
\hline $\mathbf{C u}$ & $0.06(<0.02$ to 0.08$)$ & $0.05(0.02$ to 0.07$)$ \\
\hline Mg & $1.90(1.50$ to 2.50$)$ & $3.7(3.6$ to 3.7$)$ \\
\hline $\mathbf{F e}$ & $0.10(<0.05$ to 0.10$)$ & $<0.1(<0.1$ to $<0.1)$ \\
\hline Mn & $0.01(<0.002$ to 0.02$)$ & $<0.02(<0.02$ to $<0.02)$ \\
\hline Zn & $2.26(1.20$ to 4.80$)$ & $<0.02(<0.02$ to $<0.02)$ \\
\hline
\end{tabular}

cal saline $(8.5 \mathrm{~g} / \mathrm{L} \mathrm{NaCl})$ and the solution was diluted with the sterile tap water to the required concentration before an experiment was conducted. Samples of theses bacteria collected from the experiments were assayed by heterotrophic plate count.

\section{Batch Experiments on Cadmium Adsorption onto Bacterial Surfaces}

Cadmium adsorption onto alluvial gravels has been studied by Pang and Close (1999b) using the same aquifer material and tap water as those used in this study. In the current study we focused on $\mathrm{Cd}$ adsorption onto bacteria. Gravel material was excluded from the batch experiments because preliminary tests showed that the heterogeneity of the gravel dominated the differences in the $\mathrm{Cd}$ adsorption results among samples. Known masses of bacteria (washed) and $\mathrm{Cd}$, at fixed $\mathrm{pH}$ levels (adjusted using $\mathrm{HNO}_{3}$ or $\mathrm{NaOH}$ ), were used in the batch tests. Tap water (untreated ground water) was used as the background electrolyte for all experiments. Bacteria-free controls with $\mathrm{Cd}$ only were also prepared to estimate $\mathrm{Cd}$ precipitation and adsorption onto the experimental apparatus. The batch experiments were performed in $40-\mathrm{mL}$ screw-top glass vials. The vials were placed on a shaker at room temperature $(20 \pm$ $1^{\circ} \mathrm{C}$ ) for $2 \mathrm{~h}$ to allow equilibration. An exception to this was that gentle stirring was applied in the tests on the effect of adsorption time. Once equilibrated, the suspension was filtered through a $0.45-\mu \mathrm{m}$ membrane, acidified, and analyzed for Cd concentration by flame atomic absorption spectroscopy (FAAS) (SpectAA-400; Varian, Palo Alto, CA), with a detection limit of $20 \mu \mathrm{g} / \mathrm{L}$. The difference in Cd concentration between a bacteria-free control treatment and a sample indicated adsorption of $\mathrm{Cd}$ onto the bacterial particles.

Bacillus subtilis spores and E. coli vegetative cells were used to study the effects of $\mathrm{pH}$, reaction time, and $\mathrm{Cd}$ and bacterial concentration on $\mathrm{Cd}$ adsorption. To examine the influence of surface charge and bacterial size on Cd adsorption, additional bacteria species ( $S$. menston, B. subtilis vegetative cells, E. aerogenes, and $C$. perfringens) were used. The surface charges of these bacteria were determined by measuring their zeta potential using a Zetasizer 3000 (Malvern Instruments Ltd., Malvern, UK) at the University of Otago, New Zealand, at bacte- rial concentrations of $10^{7}$ to $10^{8} \mathrm{cfu} / \mathrm{mL}$ and $\mathrm{pH}=7.5$. The bacterial particle sizes were measured by optical microscopy (Table 1).

\section{Column Experiments on Cadmium Transport}

The aquifer material was uniformly packed under saturated conditions into an acrylic column that was $18 \mathrm{~cm}$ long and had an internal diameter of $10 \mathrm{~cm}$. The repacked gravel in the column had a bulk density of $1.9 \mathrm{~g} / \mathrm{cm}^{3}$ and an effective porosity of 0.27 . This gave a pore volume (PV) of $382 \mathrm{~mL}$ for the column. Flow was supplied to the bottom of the column to remove any trapped air and to minimize the possibility of preferential flow. The bottom cap consisted of an acrylic plate with small holes, covered with fine mesh to distribute the inflow evenly.

The column was first flushed with tap water at the desired flow rate of $32.4( \pm 0.4) \mathrm{mL} / \mathrm{min}$ (i.e., about $1.0 \mathrm{PV}$ per $12 \mathrm{~min}$ ) using a peristaltic pump. These flow rates are equivalent to a pore-water velocity of $22 \mathrm{~m} / \mathrm{d}$, which is in the lower range of the typical flow velocity $(9-104 \mathrm{~m} / \mathrm{d})$ in the field for the coarse alluvial gravel aquifer investigated (Pang and Close, 1999c). Before an experiment, the $\mathrm{pH}$ of tap water was adjusted to the desired level (a fixed $\mathrm{pH}$ value between 7.0 and 7.7) using $\mathrm{HNO}_{3}$ or $\mathrm{NaOH}$ and this solution was used throughout the experiment. The column was flushed through with about 5.0 PV tap water before running an experiment. A solution containing $\mathrm{Cd}$ of approximately $4 \mathrm{mg} / \mathrm{L}$ and bromide $(\mathrm{Br})$ of approximately $2 \mathrm{mg} / \mathrm{L}$ at the fixed $\mathrm{pH}$ value was then injected for about $5 \mathrm{PV}$ before the injection of any bacteria. Bromide, as $\mathrm{KBr}$, was used as a conservative tracer to provide an independent estimation of pore-water velocity and dispersion and to examine any physical non-equilibrium processes in the experimental system. The bacteria (either B. subtilis spores or $E$. coli vegetative cells) were then introduced to the column with $\mathrm{Cd}$ and $\mathrm{Br}$ for a further 3.4 PV. After that, the column was flushed with tap water at the fixed $\mathrm{pH}$ value in the influent (no bacteria, $\mathrm{Cd}$, or $\mathrm{Br}$ ). The experiments took place at room temperature $\left(20 \pm 1^{\circ} \mathrm{C}\right)$. A series of column experiments were conducted at different bacterial input concentrations $\left(10^{3}\right.$ to $10^{7} \mathrm{cfu} / \mathrm{mL}$ ) and neutral or near-neutral $\mathrm{pH}$. The $\mathrm{pH}$ values of column inflow and effluent were monitored during the experiments and these were relatively consistent with variations of $<0.2 \mathrm{pH}$ units between the inflow and effluent. Samples were taken every 3 to $10 \mathrm{~min}$ from the column outflow. Filtered (through a $0.45-\mu \mathrm{m}$ membrane) and unfiltered samples were acidified to analyze Cd concentrations by FAAS. The $\mathrm{Br}$ concentrations were determined using a bromide ionselective electrode.

\section{Modeling}

As tailing was significant in the Cd concentration breakthrough curves (BTCs), transport of Cd was simulated using a one-dimensional two-site adsorption-desorption model (adapted from Toride et al., 1995):

$$
\begin{aligned}
& \frac{\partial c}{\partial t}+\frac{\phi}{\theta}\left(\frac{\partial S_{1}}{\partial t}+\frac{\partial S_{2}}{\partial t}\right)=D \frac{\partial^{2} c}{\partial x^{2}}-V \frac{\partial c}{\partial x} \\
& \frac{\partial S_{1}}{\partial t}=f K_{\mathrm{d}} \frac{\partial c}{\partial t} \\
& \frac{\partial S_{2}}{\partial t}=\alpha\left[(1-f) K_{\mathrm{d}} c-S_{2}\right]
\end{aligned}
$$

where $c$ is the concentration in liquid phase $(\mathrm{mg} / \mathrm{L}), D$ is the dispersion coefficient $\left(\mathrm{m}^{2} / \mathrm{h}\right), f$ is the fraction of exchange sites 
assumed to be at equilibrium, $K_{\mathrm{d}}$ is the partition coefficient for linear adsorption $(\mathrm{mL} / \mathrm{g}), S_{1}$ is the adsorbed concentration on the instantaneous adsorption site $(\mu \mathrm{g} / \mathrm{g}), S_{2}$ is the adsorbed concentration on the rate-limited adsorption site $(\mu \mathrm{g} / \mathrm{g}), t$ is time $(\mathrm{h}), v$ is the pore-water velocity $(\mathrm{m} / \mathrm{h}), x$ is distance $(\mathrm{m})$, $\alpha$ is the first-order kinetic rate coefficient $\left(\mathrm{h}^{-1}\right), \phi$ is the bulk density $\left(\mathrm{mg} / \mathrm{cm}^{3}\right)$, and $\theta$ is porosity.

The above two-site model could be reduced to a dimensionless form model (Toride et al., 1995):

$$
\begin{aligned}
& \beta R \frac{\partial C_{1}}{\partial T}=\frac{1}{P} \frac{\partial^{2} C_{1}}{\partial X^{2}}-\frac{\partial C_{1}}{\partial X}-\omega\left(C_{1}-C_{2}\right) \\
& (1-\beta) R \frac{\partial C_{2}}{\partial T}=\omega\left(C_{1}-C_{2}\right)
\end{aligned}
$$

by using the following dimensionless parameters:

$$
\begin{aligned}
& T=\frac{\nu t}{L} \quad X=\frac{x}{L} \quad P=\frac{\nu L}{D} \quad C_{1}=\frac{c}{c_{0}} \quad C_{2}=\frac{S_{2}}{(1-f) K_{\mathrm{d}} c_{0}} \\
& R=1+\frac{\phi K_{\mathrm{d}}}{\theta} \quad \beta=\frac{\theta+f \phi K_{\mathrm{d}}}{\theta+\phi K_{\mathrm{d}}} \quad \omega=\frac{\alpha(1-\beta) R L}{\nu} \quad[6]
\end{aligned}
$$

where $c_{0}$ is the input concentration $(\mathrm{mg} / \mathrm{L}) ; L$ is the characteristic length (m); $T, X$, and $C$ are dimensionless time (i.e., pore volume), length, and concentration, respectively; the subscripts 1 and 2 refer to equilibrium and kinetic adsorption sites, respectively; $P$ is the Peclet number; $R$ is the retardation factor; $\beta$ is the partitioning coefficient between the equilibrium and non-equilibrium phases, representing the fraction of instantaneous adsorption sites in the two-site model; and $\omega$ is a dimensionless mass transfer coefficient. The degree of chemical nonequilibrium is reflected in the magnitude of $\beta$ and $\omega$. A unity value of $\beta$ indicates equilibrium conditions (Toride et al., 1995), and when $\omega$ is $\geq 10$, the local equilibrium assumption appears to be reasonably approximated (Brusseau et al., 1991).

Bacterial BTCs are simulated using an advection-dispersion model that is coupled with first-order attachment-detachment kinetics (Hornberger et al., 1992; McCaulou et al., 1994):

$$
\begin{aligned}
& \frac{\partial c}{\partial t}=D \frac{\partial^{2} c}{\partial x^{2}}-v \frac{\partial c}{\partial x}-\frac{\phi}{\theta} \frac{\partial S}{\partial t} \\
& \frac{\phi}{\theta} \frac{\partial S}{\partial t}=k_{\mathrm{att}} c-\frac{\phi}{\theta} k_{\mathrm{det}} S
\end{aligned}
$$

where $c$ is the concentration of free bacteria $(\mathrm{cfu} / 100 \mathrm{~mL}), S$ is the concentration of attached bacteria $(\mathrm{cfu} / \mathrm{g})$, and $k_{\text {att }}$ and $k_{\text {det }}$ are the first-order attachment rate and detachment rate, respectively $\left(\mathrm{h}^{-1}\right)$. Bacterial die-off was ignored as the duration of bacterial involvement in the experiments was less than $2 \mathrm{~h}$. As tailing was not significant in the bacterial BTCs, it is suggested that the microbial attachment observed in this study was predominantly an irreversible process and detachment is negligible (i.e., $k_{\text {det }}=0$ ). Therefore, Eq. [7] and [8] are reduced to a traditional advection-dispersion equation (ADE), with a first-order reduction term:

$$
\frac{\partial c}{\partial t}=D \frac{\partial^{2} c}{\partial x^{2}}-v \frac{\partial c}{\partial x}-k_{\mathrm{att}} c
$$

which has a dimensionless form of:

$$
\frac{\partial C_{1}}{\partial T}=\frac{1}{P} \frac{\partial^{2} C_{1}}{\partial X^{2}}-\frac{\partial C_{1}}{\partial X}-\mu C_{1}
$$

where $\mu=\frac{L k_{\text {att }}}{v}$. Equation [10] was also applied to the $\mathrm{Br}$ BTCs by setting $\mu=0$.
We estimated values of $v$ and $D$ independently for the $\mathrm{Br}$ and bacterial data because bacteria (as colloids) and solutes follow different flow paths and bacteria are less diffusive compared with most solutes (Johnson et al., 1995). The $v$ and $D$ values estimated from the $\mathrm{Br}$ data were then held constant, while $R, \beta$, and $\omega$ were optimized for the $\mathrm{Cd}$ data. Parameter estimations using $\mathrm{Br}$, bacteria, and $\mathrm{Cd}$ data were performed with the curve-fitting program, CXTFIT 2.0 (Toride et al., 1995), because both the two-site adsorption-desorption model and the ADE are incorporated in the program. Knowing $\phi=1.9$ $\mathrm{g} / \mathrm{cm}^{3}$ and $\theta=0.27$ as given previously, values of $K_{\mathrm{d}}, f$, and $\alpha$ for the $\mathrm{Cd}$ data were then calculated from the formulae listed in Eq. [6]

A Cd BTC can be divided into three portions according to the way that the tracers were introduced: Step $1, \mathrm{Cd}$ and $\mathrm{Br}$ only added at the influent; Step 2, $\mathrm{Cd}, \mathrm{Br}$ and bacteria added at the influent; and Step 3, no tracers added at the influent, only flushing with tap water. When bacteria-facilitated transport did not occur, Steps 1 and 2 in a Cd BTC are shown as an ascending limb, and when bacteria-facilitated transport occurred, Step 2 in a Cd BTC is shown as a plateau (refer to discussion of Fig. 3 and 4 in Results and Discussion, below). Step 3 is always shown as a descending limb. In addition to fitting the whole Cd BTC, curve-fitting was also performed for the individual portions of a Cd BTC.

It should be noted that while the modeling approach outlined above simplified the complex interactions among $\mathrm{Cd}$, aquifer media, and bacteria, it described the overall transport of $\mathrm{Cd}$ in relation to the conservative tracer, $\mathrm{Br}$. If the two adsorption processes are to be differentiated, a transport model that is coupled with a metal-bacteria surface complexation model should be used to consider the interactions between $\mathrm{Cd}$ and bacteria. However, such a transport model was not available to the authors at the time of writing this paper. The experimental results (refer to Results and Discussion, below) showed that for each portion of a BTC, the transport of $\mathrm{Cd}$ was dominated by different components, the aquifer media for the ascending and descending limbs, and the bacteria for the plateau step. Therefore, we used the CXTFIT transport model to simulate our experimental data, treating Cd adsorption onto the bacteria in a similar fashion as its adsorption onto the aquifer media.

\section{RESULTS AND DISCUSSION Batch Experiments}

Results obtained from the batch adsorption experiments are shown in Fig. 1 and 2. The major findings of the batch experiments are described below.

Cadmium adsorption onto B. subtilis spores and E. coli increased linearly as $\mathrm{pH}$ increased from $\mathrm{pH}=6.0$ to 8.0 (Fig. 1a). Cadmium adsorption became less linear when the $\mathrm{pH}$ values were extended to a wider range $(\mathrm{pH}=$ 3-8). This effect of $\mathrm{pH}$ is expected because as $\mathrm{pH}$ increases, the surface charge of $B$. subtilis becomes progressively more negative (Harden and Harris, 1952); this may also occur with E. coli. At similar $\mathrm{pH}$ levels, bacterial concentrations, and $\mathrm{Cd}$ concentrations, $\mathrm{Cd}$ adsorption onto B. subtilis spores was much greater than Cd adsorption onto E. coli (Fig. 1a, 1c).

The distinctly lower adsorption of $\mathrm{Cd}$ onto $E$. coli than onto $B$. subtilis spores is thought to be due to fundamental differences in the structural and chemical properties of the cell walls of gram-positive and gram-negative bac- 


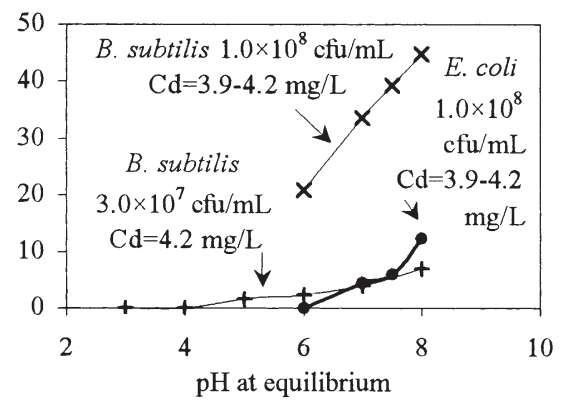

(a)

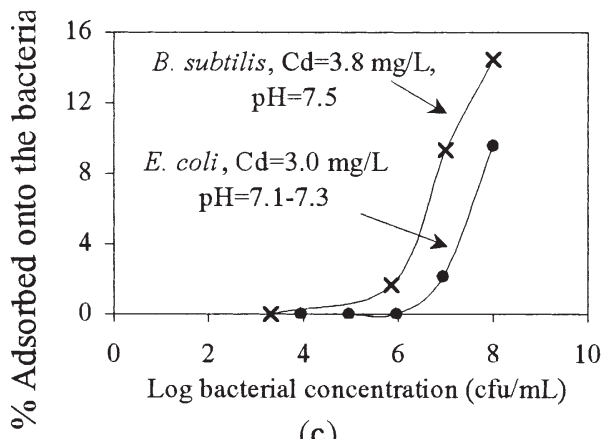

(c)

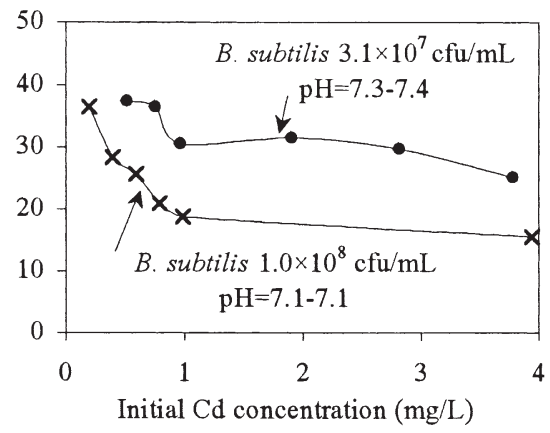

(e)

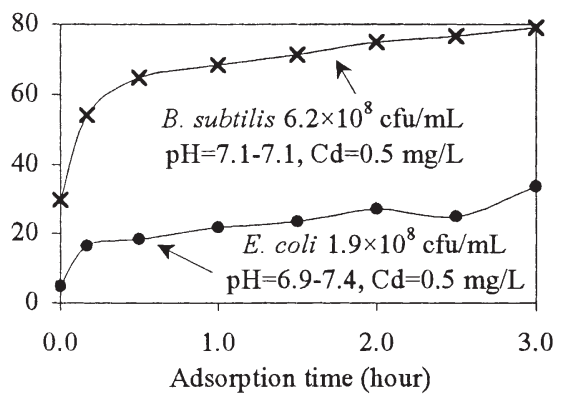

(b)

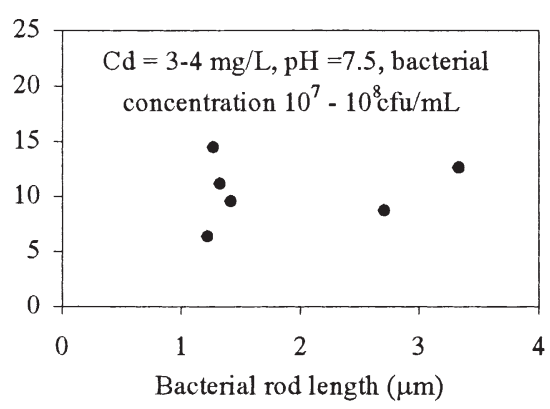

(d)

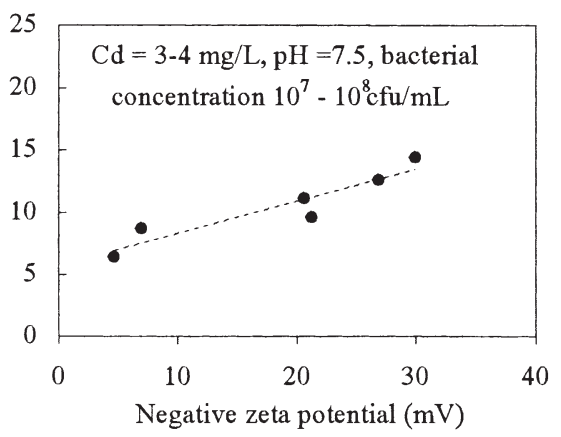

(f)

Fig. 1. Results of batch experiments on Cd adsorption onto bacteria surface: effect of (a) solution pH, (b) adsorption time, (c) bacterial concentration, (d) bacterial cell size, (e) Cd concentration, and (f) surface charge of the bacterial cells.

teria. The cell walls of gram-negative bacteria are more complex than those of gram-positive bacteria, they have a lower charge capacity and do not bind as much metal to the surface (Beveridge and Koval, 1981). Escherichia coli is a gram-negative bacterial species that can secrete molecules, which efficiently chelate metals (Beveridge and Koval, 1981). In a review by Beveridge (1999), gramnegative bacterial cells walls were described as possessing a dynamic feature that is not present in their grampositive counterparts: during bacterial growth, the surface of gram-negative bacterial cells constantly secretes outer membrane vesicles that are 50 to $250 \mathrm{~nm}$ in diameter, and soluble secretion products can be found readily in the external fluid once they are free of the bacteria cell. Fein et al. (2002) also indicated that gram-negative cell walls contain outer membrane extracellular polysaccharides, but gram-positive cell walls do not contain such extracellular compounds. Escherichia coli was also found to adsorb less Cd than B. subtilis in other studies (Mar- tinez and Ferris, 2001; Kulczycki et al., 2002). In our experiments, filtration of Cd samples using the $0.45-\mu \mathrm{m}$ membrane would have excluded $E$. coli cells $(>1.0 \mu \mathrm{m})$, but would have included the secretion molecules. It is thought that the dissolved metal-chelating molecules would have chelated $\mathrm{Cd}$ in solution and competed with the available $\mathrm{Cd}$ for the bacterial surface, thereby reducing the observed degree of adsorption onto the E. coli cells.

Cadmium adsorption onto B. subtilis spores and E. coli cells increased as the bacterial concentration increased (Fig. 1c), with little adsorption taking place until bacterial concentrations were greater than $10^{6} \mathrm{cfu} / \mathrm{mL}$. The threshold value of $10^{6} \mathrm{cfu} / \mathrm{mL}$ observed here related to $\mathrm{Cd}$ input concentrations of 3 to $4 \mathrm{mg} / \mathrm{L}$, and this may vary with $\mathrm{Cd}$ concentration. At a fixed concentration of bacteria, the proportion of $\mathrm{Cd}$ adsorption onto the bacteria decreased as the $\mathrm{Cd}$ concentration increased (Fig. 1e). This is because there were relatively more 


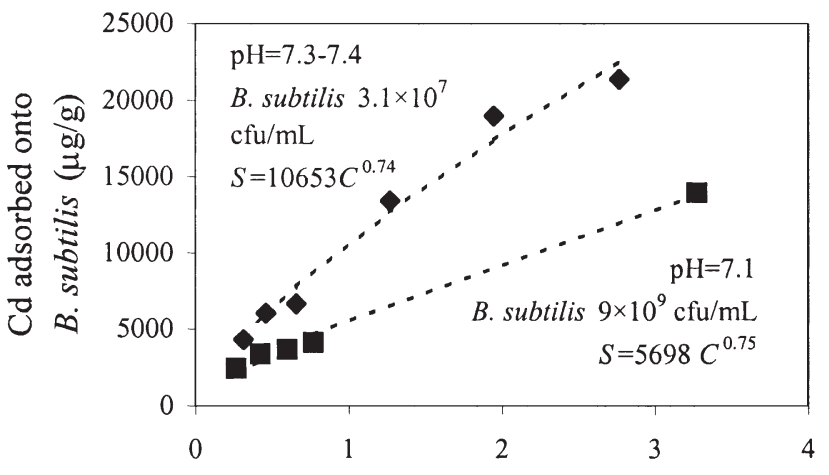

Cd equilibrium concentration $(\mathrm{mg} / \mathrm{L})$

Fig. 2. Cadmium-Bacillus subtilis adsorption isotherms. Observed data are in dots and Freundlich function-simulated data are in dashed lines.

$\mathrm{Cd}^{2+}$ ions and fewer bacterial adsorption sites in the system. This suggests that the higher the concentration ratio of bacteria to $\mathrm{Cd}$, the greater the level of adsorption of $\mathrm{Cd}$ onto the bacteria.

There are some discrepancies in the proportion of $\mathrm{Cd}$ adsorbed to B. subtilis spores between Fig. 1a and 1c under similar conditions of $\mathrm{pH}, \mathrm{Cd}$ loading, and bacterial concentration. This is largely because different batches of tap water were used at different times, resulting in variations in the background water chemistry. The variations in tap water chemistry are shown in Table 2. As a result of variations in Cd adsorption between experiments, the most useful information obtained from the batch experiments in this study mainly related to the trends derived from the experimental results and not the amount of $\mathrm{Cd}$ adsorption onto the bacteria.

As would be expected, the adsorption of $\mathrm{Cd}$ onto the bacteria increased when bacterial surfaces were more negatively charged (indicated by the zeta potential) as shown in Fig. 1f. While the size of the bacteria has been observed to influence the adsorption of metal onto the bacterial surface (Cotoras et al., 1992; Karathanasis, 2000), no clear relationship could be determined between the adsorption of $\mathrm{Cd}$ onto the bacteria and bacterial size from our experimental data (Fig. 1d).

Figure $1 \mathrm{~b}$ shows that the adsorption of $\mathrm{Cd}$ onto both $B$. subtilis spores and E. coli was rate-limited. Under similar experimental conditions, adsorption of $\mathrm{Cd}$ onto the $B$. subtilis spores was much greater than adsorption of $\mathrm{Cd}$ onto E . coli. It should be noted that the results have excluded the adsorption of Cd onto any dissolved organic compounds or small membrane vesicles derived from $E$. coli cell walls, which would have passed through the filter paper during the sampling. The kinetic adsorption of Cd onto B. subtilis spores and E. coli was in contrast to studies by Fowle and Fein (2000), who observed a rapid adsorption of Cd onto B. subtilis vegetative cells, and by Yee and Fein (2001), who observed that $\mathrm{Cd}$ adsorption onto $E$. coli reached equilibrium in $4 \mathrm{~h}$. These apparent discrepancies in the results of the current study are probably because of the different experimental conditions (e.g., bacterial and Cd concentrations, background electrolyte, and ionic strength) used.

Cadmium adsorption onto B. subtilis spores was nonlinear and fitted well with Freundlich isotherms (Fig. 2).
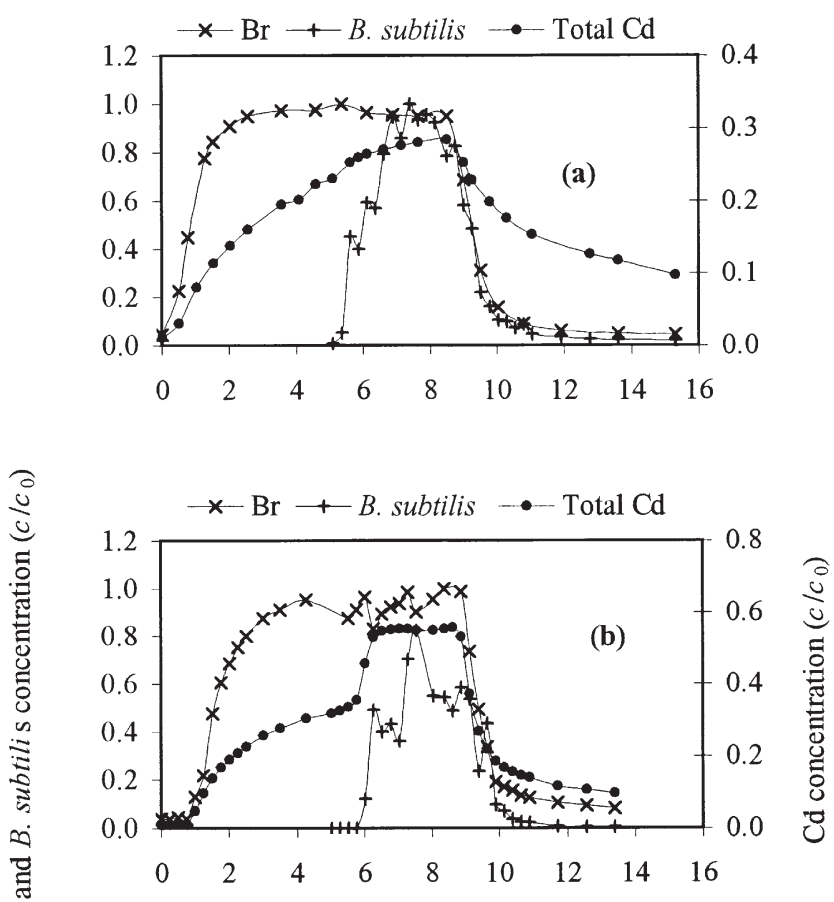

苟

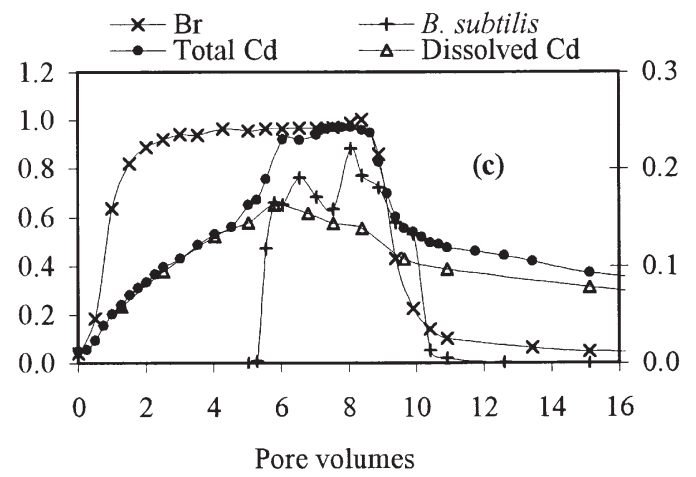

Fig. 3. Results of column experiments on Cd transport with Bacillus subtilis spore input concentrations of (a) $9 \times 10^{4}$ colony-forming units (cfu)/mL, pH = 7.0; (b) $7 \times 10^{5} \mathrm{cfu} / \mathrm{mL}, \mathrm{pH}=7.7$; and (c) $5.6 \times 10^{7} \mathrm{cfu} / \mathrm{mL}, \mathrm{pH}=7.0$. The spores were introduced after about 5 pore volumes injection of $\mathrm{Cd}$ and $\mathrm{Br}$.

The values of the partition coefficient $(K)$ varied with $\mathrm{pH}$ and spore concentration, ranging from $K=5.70 \times$ $10^{3}(\mathrm{~mL} / \mathrm{g})^{0.75}$ to $1.07 \times 10^{4}(\mathrm{~mL} / \mathrm{g})^{0.74}$. However, the exponent $n$ was very constant, ranging from 0.74 to 0.75 . Using the same aquifer material and tap water as those used in this study, Pang and Close (1999b) derived a $K=17$ $(\mathrm{mL} / \mathrm{g})^{0.52}$ for Cd-alluvial gravel adsorption. In comparison, the above $K$ values for $\mathrm{Cd}-B$. subtilis adsorption derived from the present study are three orders of magnitude greater. The $K$ and $n$ values were derived from fitting the isotherm data with a power function.

\section{Column Experiments}

Figures 3 and 4 show the observed BTCs of $\mathrm{Cd}, \mathrm{Br}$, and bacteria from the column experiments. The earlier appearance of $\mathrm{Cd}$ and $\mathrm{Br}$, as shown in their BTCs, compared with the later appearance of the bacteria was because the bacteria were introduced after $5 \mathrm{PV}$ of $\mathrm{Cd}$ 

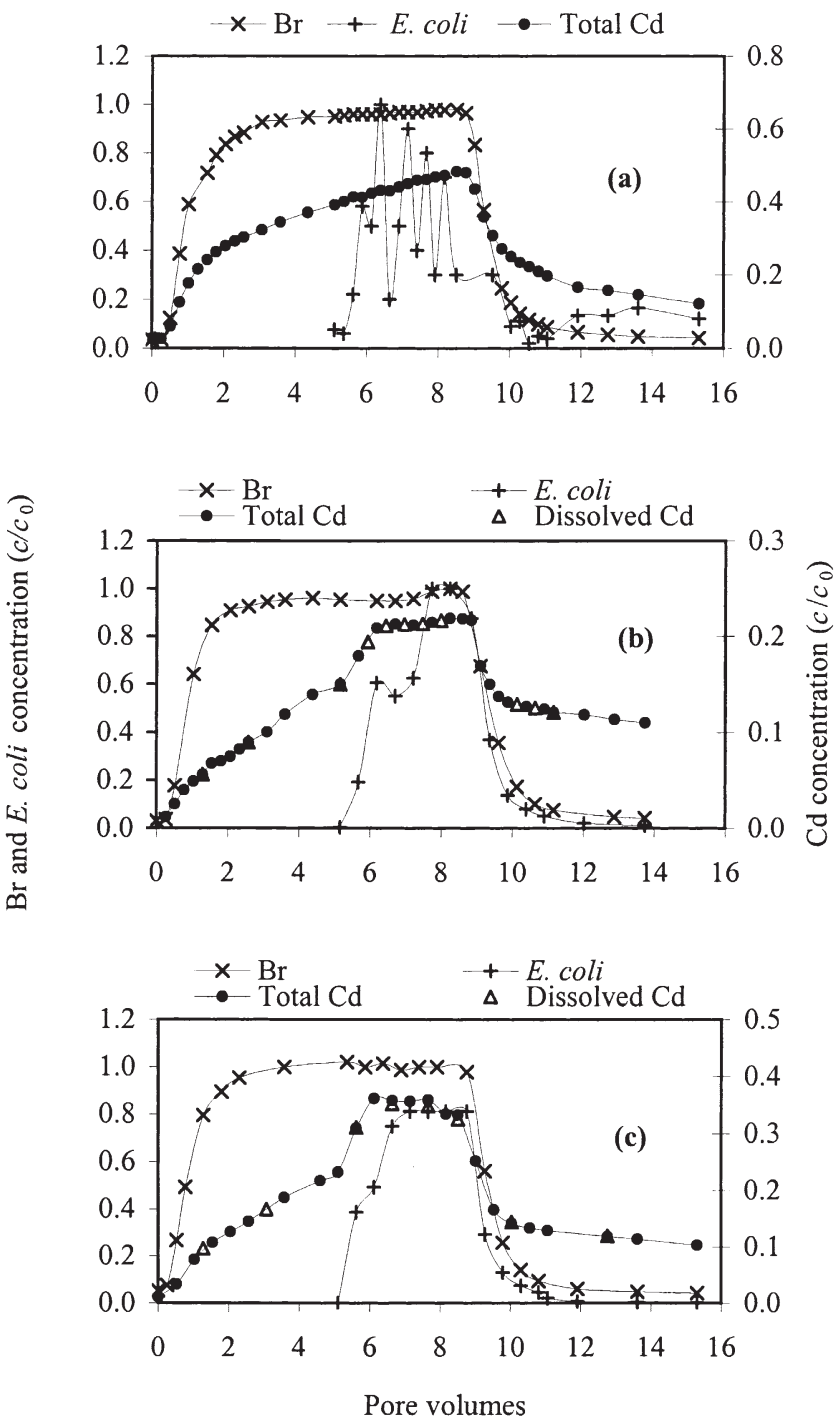

Fig. 4. Results of column experiments on Cd transport with Escherichia coli input concentrations of (a) $5 \times 10^{3}$ colony-forming units (cfu) $/ \mathrm{mL}, \mathrm{pH}=7.5$; (b) $1.6 \times 10^{5} \mathrm{cfu} / \mathrm{mL}, \mathrm{pH}=7.0$; and (c) $3.7 \times$ $10^{7} \mathrm{cfu} / \mathrm{mL}, \mathrm{pH}=7.0$. Escherichia coli were introduced after about 5 pore volumes injection of $\mathrm{Cd}$ and $\mathrm{Br}$.

and $\mathrm{Br}$ had been injected. Figures 5, 6, and 7 compare CXTFIT-simulated concentrations with the observed concentrations of $\mathrm{Br}$, bacteria, and $\mathrm{Cd}$. Values of transport parameters optimized from CXTFIT and subsequently calculated are listed in Tables 3 and 4.

Figures 3 and 4 show that when B. subtilis and E. coli input concentrations were $\geq 10^{5} \mathrm{cfu} / \mathrm{mL}$, there was a steep rise and a flat symmetrical plateau in Cd BTCs after injection of the bacteria. This threshold value of $10^{5} \mathrm{cfu} / \mathrm{mL}$ for significant bacteria-facilitated $\mathrm{Cd}$ transport is one order of magnitude lower than that observed in the batch study for significant adsorption of $\mathrm{Cd}$ onto the bacteria. As indicated from the results of the batch study, the degree of $\mathrm{Cd}$ adsorption onto bacteria is very sensitive to Cd concentration or the concentration ratio of bacteria to $\mathrm{Cd}$ (Fig. 1e) and the $\mathrm{pH}$ value (Fig. 1a). Hence, a slight change in these conditions may result in a significant change in the results. Therefore, this threshold value

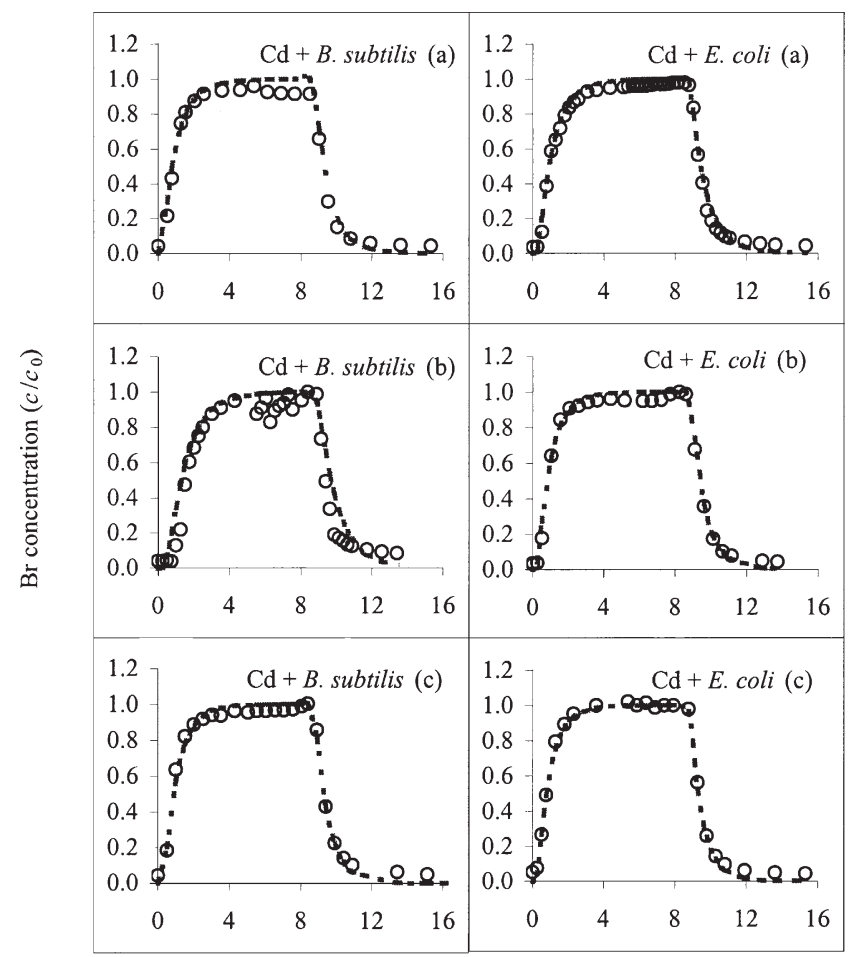

Pore volumes

Fig. 5. Observed (dots) and CXTFIT-simulated (dashed line) Br concentrations from the equilibrium model. For $\mathrm{Cd}+$ Bacillus subtilis experiments: (a) input concentration $\left(c_{0}\right)=9 \times 10^{4}$ colony-forming units (cfu)/mL, pH = 7.0; (b) $c_{0}=7 \times 10^{5} \mathrm{cfu} / \mathrm{mL}, \mathrm{pH}=7.7$; and (c) $c_{0}=5.6 \times 10^{7} \mathrm{cfu} / \mathrm{mL}, \mathrm{pH}=7.0$. For Cd + Escherichia coli experiments: (a) $c_{0}=5 \times 10^{3} \mathrm{cfu} / \mathrm{mL}, \mathrm{pH}=7.5$; (b) $c_{0}=1.6 \times$ $10^{5} \mathrm{cfu} / \mathrm{mL}, \mathrm{pH}=7.0$; and (c) $c_{0}=3.7 \times 10^{7} \mathrm{cfu} / \mathrm{mL}, \mathrm{pH}=7.0$.

of the bacterial concentration may be specific to the experimental conditions. For example, in a field study by Pang and Close (1999a), 33\% of the Cd mass recovered in a well was cotransported with $B$. subtilis spores when the bacterial concentrations were $10^{4} \mathrm{cfu} / \mathrm{mL}$ and $\mathrm{Cd}$ concentrations were less than $700 \mu \mathrm{g} / \mathrm{L}$. However, the bacterial and $\mathrm{Cd}$ concentrations in the injection well would have been much greater than these values. The effect of concentration observed in the current study suggests that in a field situation, the closer the proximity of a metal to a bacterial contamination source, the more likely it is that bacteria-facilitated transport will occur.

The shape of the plateau step in Fig. 3 and 4 is similar to that of the bacterial BTC, suggesting that Cd was cotransported with the bacteria when they were introduced. When Cd was cotransported with $B$. subtilis spores, there was a significant difference between concentrations of dissolved and total $\mathrm{Cd}$ (Fig. 3c), suggesting that a significant amount of $\mathrm{Cd}$ was adsorbed onto the $B$. subtilis spores. Some Cd could also have precipitated onto the $B$. subtilis spores and consequently traveled with $B$. subtilis spores. Precipitation of $\mathrm{Cd}$ in tap water used in this study had been previously assessed and it is believed to have been predominantly precipitated as $\mathrm{CdCO}_{3}$ (Pang and Close, 1999b), which is insoluble (Aylward and Findlay, 1974). Where Cd was cotransported with E. coli, the dissolved $\mathrm{Cd}$ concentrations were almost the same as 


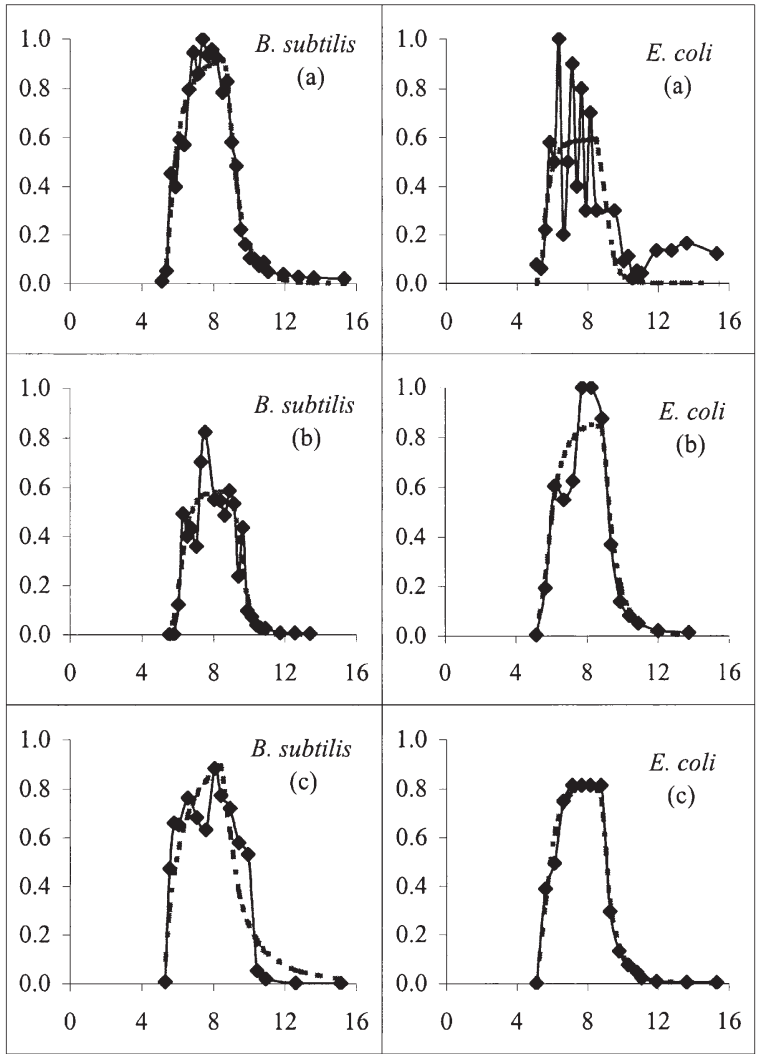

Pore volumes

Fig. 6. Observed (dots) and CXTFIT-simulated (dashed line) bacteria concentrations. Bacteria were introduced after about 5 pore volumes injection of $\mathrm{Cd}$ and $\mathrm{Br}$. For $\mathrm{Cd}+$ Bacillus subtilis experiments: (a) input concentration $\left(c_{0}\right)=9 \times 10^{4}$ colony-forming units (cfu) $/ \mathrm{mL}, \mathbf{p H}=7.0$; (b) $c_{0}=7 \times 10^{5} \mathrm{cfu} / \mathrm{mL}, \mathbf{p H}=7.7$; and (c) $c_{0}=5.6 \times 10^{7} \mathrm{cfu} / \mathrm{mL}, \mathrm{pH}=7.0$. For Cd + Escherichia coli experiments: (a) $c_{0}=5 \times 10^{3} \mathrm{cfu} / \mathrm{mL}, \mathrm{pH}=7.5$; (b) $c_{0}=1.6 \times$ $10^{5} \mathrm{cfu} / \mathrm{mL}, \mathrm{pH}=7.0$; and (c) $c_{0}=3.7 \times 10^{7} \mathrm{cfu} / \mathrm{mL}, \mathrm{pH}=7.0$.

the total $\mathrm{Cd}$ concentrations (Fig. 4b, 4c). This suggests that little $\mathrm{Cd}$ was adsorbed onto $E$. coli cells and that the introduction of $E$. coli seemed to increase the apparent solubility of $\mathrm{Cd}$. An increase in the soluble metal frac-

Table 3. Flow and transport parameters derived from $\mathrm{Br}$ and bacteria breakthrough curves (BTCs).

\begin{tabular}{|c|c|c|c|c|c|c|c|c|}
\hline \multirow[b]{2}{*}{ Experiment $\dagger$} & \multicolumn{2}{|c|}{$V$} & \multicolumn{2}{|c|}{$D$} & \multicolumn{2}{|c|}{$k_{\text {att }}$} & \multirow[b]{2}{*}{$r^{2}$} & \multirow{2}{*}{$\begin{array}{c}V_{\mathrm{Br}} \text { to } V_{\text {micr }} \\
\text { ratio }\end{array}$} \\
\hline & Value & $\mathrm{SE} \neq$ & Value & SE & Value & SE & & \\
\hline & \multicolumn{2}{|c|}{$-\mathbf{m} / \mathbf{h}-$} & \multicolumn{2}{|c|}{$-\mathbf{m}^{2} / \mathbf{h}-$} & \multicolumn{2}{|c|}{$-h^{-1}-$} & & \\
\hline \multicolumn{9}{|l|}{ From Br data } \\
\hline Cd + B. subtilis (a) & 0.87 & 0.05 & 0.06 & 0.01 & & & 0.98 & \\
\hline $\mathbf{C d}+\boldsymbol{B}$. subtilis (b) & 0.56 & 0.04 & 0.02 & 0.01 & & & 0.92 & \\
\hline Cd + B. subtilis (c) & 0.81 & 0.03 & 0.04 & 0.00 & & & 0.99 & \\
\hline $\mathbf{C d}+E$. coli (a) & 0.77 & 0.02 & 0.05 & 0.00 & & & 0.99 & \\
\hline Cd + E. coli (b) & 0.89 & 0.03 & 0.05 & 0.01 & & & 0.99 & \\
\hline Cd + E. coli $(\mathbf{c})$ & 0.91 & 0.03 & 0.05 & 0.00 & & & 1.00 & \\
\hline \multicolumn{9}{|l|}{ From bacteria data } \\
\hline Cd + B. subtilis (a) & 0.94 & 0.07 & 0.06 & 0.01 & 0.39 & 0.18 & 0.97 & 0.93 \\
\hline Cd + B. subtilis (b) & 0.66 & 0.06 & 0.01 & 0.01 & 2.07 & 0.33 & 0.86 & 0.84 \\
\hline Cd + B. subtilis (c) & 0.59 & 0.23 & 0.09 & 0.04 & 0.00 & 0.51 & 0.80 & 1.38 \\
\hline Cd + E. coli (a) & 1.08 & 0.74 & 0.06 & 0.09 & 3.66 & 2.33 & 0.55 & 0.71 \\
\hline Cd + E. coli $(\mathbf{b})$ & 0.86 & 0.14 & 0.05 & 0.03 & 0.70 & 0.41 & 0.93 & 1.03 \\
\hline Cd + E. coli (c) & 0.96 & 0.08 & 0.07 & 0.02 & 1.02 & 0.22 & 0.99 & 0.95 \\
\hline
\end{tabular}

$\dagger$ The terms a, b, and c correspond with the different experimental conditions described in Fig. 3 through 7.

$\uparrow$ Standard error of the model estimation.

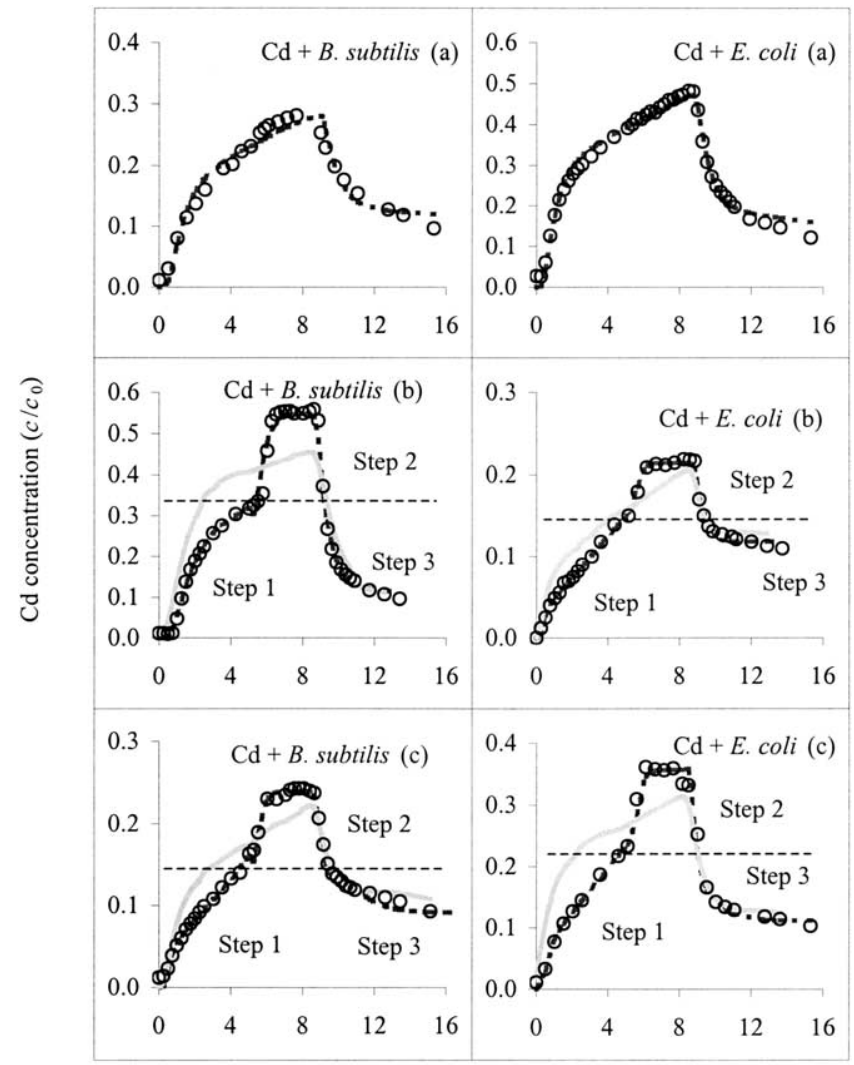

Pore volumes

Fig. 7. Observed (dots) and CXTFIT-simulated (dashed line) Cd concentrations from the two-site adsorption-desorption nonequilibrium model for the individual portions. The shaded lines show model fitting for the whole breakthrough curves. For Cd + Bacillus subtilis experiments: (a) input concentration $\left(c_{0}\right)=9 \times 10^{4}$ colonyforming units (cfu)/mL, $\mathbf{p H}=7.0 ;$ (b) $c_{0}=7 \times 10^{5} \mathrm{cfu} / \mathrm{mL}, \mathbf{p H}=$ 7.7; and (c) $c_{0}=5.6 \times 10^{7} \mathrm{cfu} / \mathrm{mL}, \mathrm{pH}=7.0$. For Cd + Escherichia coli experiments: (a) $c_{0}=5 \times 10^{3} \mathrm{cfu} / \mathrm{mL}, \mathrm{pH}=7.5$; (b) $c_{0}=1.6 \times$ $10^{5} \mathrm{cfu} / \mathrm{mL}, \mathrm{pH}=7.0$; and (c) $c_{0}=3.7 \times 10^{7} \mathrm{cfu} / \mathrm{mL}, \mathrm{pH}=7.0$.

tion with the introduction of colloids was also observed in the studies of Karathanasis $(1999,2000)$. The clear differences between the cotransport of $\mathrm{Cd}$ with $E$. coli and $B$. subtilis spores discussed above is thought to be due to the presence of Cd-complexing ligands that compete with the bacterial surface for the available $\mathrm{Cd}$, as discussed previously. Alternatively these differences might be due to a lower capacity of the gram-negative bacterial species to adsorb the metal.

Figures 5 and 6 show that the advection-dispersion equation (with a first-order reduction term) fitted well both the $\mathrm{Br}$ and bacterial BTCs that have little tailing. The two-site adsorption-desorption model simulated the Cd BTCs well in the absence of bacteria-facilitated transport (Fig. 7a). In the presence of bacteria-facilitated transport, the two-site model failed to fit the whole BTC except for the individual steps of the BTCs (Fig. 7b, 7c). This is because the predominant interactions were different at various stages of $\mathrm{Cd}$ transport, dominated by the aquifer media for the ascending and descending steps and by the bacteria for the plateau step. However, when treating $\mathrm{Cd}$ adsorption onto the bacteria in a similar fashion as $\mathrm{Cd}$ adsorption onto the aquifer media, the 
Table 4. Parameters of $\mathrm{Cd}$ transport derived from the two-site adsorption-desorption model and parameters subsequently calculated.

\begin{tabular}{|c|c|c|c|c|c|c|c|c|c|c|c|c|c|}
\hline \multirow[b]{2}{*}{ Experiment $\dagger$} & \multirow{2}{*}{$\begin{array}{l}\text { Portion of } \\
\text { the BTC }\end{array}$} & \multirow[b]{2}{*}{ Step } & \multirow[b]{2}{*}{$V \S$} & \multicolumn{2}{|c|}{$\boldsymbol{R}$} & \multicolumn{2}{|c|}{$\boldsymbol{\beta}$} & \multicolumn{2}{|c|}{$\omega$} & \multirow[b]{2}{*}{$f$} & \multirow[b]{2}{*}{$a$} & \multirow[b]{2}{*}{$K_{\mathrm{d}}$} & \multirow[b]{2}{*}{$r^{2}$} \\
\hline & & & & Value & SEII & Value & SE & Value & SE & & & & \\
\hline & & & $\mathbf{m} / \mathbf{h}$ & & & & & & & & $\mathbf{h}^{-1}$ & $\mathbf{g} / \mathbf{m L}$ & \\
\hline \multicolumn{14}{|c|}{ Cd + B. subtilis } \\
\hline \multirow[t]{3}{*}{ a } & whole & $1,2,3$ & 0.87 & 38.72 & 2.34 & 0.08 & 0.00 & 2.84 & 0.10 & 0.05 & 0.38 & 5.36 & 0.96 \\
\hline & ascending & 1,2 & 0.87 & 26.85 & 1.85 & 0.10 & 0.01 & 3.37 & 0.20 & 0.06 & 0.68 & 3.67 & 0.99 \\
\hline & descending & 3 & 0.87 & 41.43 & 3.25 & 0.08 & 0.01 & 3.01 & 0.20 & 0.06 & 0.38 & 5.75 & 0.95 \\
\hline \multirow[t]{3}{*}{ b } & ascending & 1 & 0.56 & 14.98 & 3.43 & 0.12 & 0.03 & 1.80 & 0.10 & 0.06 & 0.42 & 1.99 & 1.00 \\
\hline & plateau & 2 & 0.56 & 0.88 & 0.62 & 1.00 & 85.65 & 49.67 & $1.77 \times 10^{6}$ & 1.01 & $1.76 \times 10^{5}$ & 0.00 & 0.88 \\
\hline & descending & 3 & 0.56 & 15.22 & 2.91 & 0.07 & 0.00 & 1.24 & 0.20 & -0.00 & 0.27 & 2.02 & 0.98 \\
\hline \multirow[t]{3}{*}{ c } & ascending & 1 & 0.81 & 22.62 & 1.28 & 0.07 & 0.01 & 5.31 & 0.23 & 0.02 & 1.13 & 3.07 & 0.99 \\
\hline & plateau & 2 & 0.81 & 1.32 & 0.12 & 1.00 & 0.39 & 0.10 & 274.50 & 1.00 & 342.15 & 0.05 & 0.94 \\
\hline & descending & 3 & 0.81 & 55.33 & 3.52 & 0.12 & 0.01 & 4.29 & 0.21 & 0.10 & 0.39 & 7.72 & 0.84 \\
\hline \multicolumn{14}{|l|}{ Cd + E. coli } \\
\hline \multirow[t]{3}{*}{$\mathbf{a}$} & whole & $1,2,3$ & 0.77 & 16.19 & 0.43 & 0.10 & 0.00 & 1.64 & 0.04 & 0.04 & 0.48 & 2.16 & 0.99 \\
\hline & ascending & 1,2 & 0.77 & 13.07 & 0.29 & 0.11 & 0.00 & 1.93 & 0.04 & 0.04 & 0.71 & 1.72 & 1.00 \\
\hline & descending & 3 & 0.77 & 16.89 & 0.92 & 0.10 & 0.00 & 1.58 & 0.07 & 0.04 & 0.44 & 2.26 & 0.98 \\
\hline \multirow[t]{3}{*}{ b } & ascending & 1 & 0.89 & 24.75 & 0.86 & 0.06 & 0.00 & 6.40 & 0.20 & 0.02 & 1.36 & 3.38 & 0.99 \\
\hline & plateau & 2 & 0.89 & 1.42 & 0.95 & 1.00 & 77.79 & 71.06 & $2.50 \times 10^{6}$ & 1.00 & $2.46 \times 10^{5}$ & 0.06 & 0.94 \\
\hline & descending & 3 & 0.89 & 46.65 & 0.94 & 0.05 & 0.01 & 4.87 & 0.28 & 0.03 & 0.54 & 6.49 & 0.94 \\
\hline \multirow[t]{3}{*}{ c } & ascending & 1 & 0.91 & 18.47 & 0.84 & 0.09 & 0.01 & 4.29 & 0.19 & 0.04 & 1.29 & 2.48 & 1.00 \\
\hline & plateau & 2 & 0.91 & 0.93 & 3.91 & 1.00 & 10.17 & 0.10 & $4.09 \times 10^{5}$ & 1.00 & $\mathbf{5 4 6 8 . 2 5}$ & 0.00 & 0.84 \\
\hline & descending & 3 & 0.91 & $\mathbf{5 0 . 5 8}$ & 1.91 & 0.09 & 0.01 & 4.38 & 0.25 & 0.08 & 0.49 & 7.05 & 0.93 \\
\hline
\end{tabular}

$\dagger$ The terms a, b, and c correspond with the different experimental conditions described in Fig. 3 through 7.

$\uparrow$ BTC, breakthrough curve.

$\S$ Velocity estimated from Br data.

II Standard error of the model estimation.

model could fit well with the plateau step (i.e., the half square box) alone. Model-derived results for the plateau step give $\beta=1$ and $f=1$ (Table 4 ), suggesting that the equilibrium process was dominant during metalbacteria cotransport. This conclusion is also supported by the symmetrical shape of the Cd BTCs in the plateau step.

The Cd $R$ values of 0.9 to 1.4 estimated for the plateau (Fig. 7b, 7c; Table 4) when bacteria were introduced are very similar to the $\mathrm{Br}$ to bacteria velocity ratio of 0.8 to 1.4 (Table 3 ), which strongly suggests that $\mathrm{Cd}$ was cotransported with the bacteria. As indicated by the results of the batch study, the adsorption coefficients of $\mathrm{Cd}$ onto bacteria are three orders of magnitude greater than those of $\mathrm{Cd}$ adsorption onto the aquifer material. Therefore, when Cd transport is facilitated by the bacteria, the overall driving force for $\mathrm{Cd}$ transport will be dominated by bacteria and the effect of aquifer media will become insignificant.

In comparison with the $R$ values for Step 1 (Fig. 7b, $7 \mathrm{c}$; Table 4) where no bacteria were injected, the estimated $R$ values were 17 to 20 times lower for Step 2 but mostly 2 to 3 times higher for Step 3 when there was bacteria-facilitated $\mathrm{Cd}$ transport (Table 4). This indicates that adsorption of $\mathrm{Cd}$ onto mobile bacteria reduced the retardation of $\mathrm{Cd}$ in the column, while adsorption of $\mathrm{Cd}$ onto bacteria that were retained in the column increased the retardation of $\mathrm{Cd}$ because the residual bacteria in the column provided another sorbent in addition to the aquifer material for $\mathrm{Cd}$ adsorption. Similarly, Yee and Fein (2002) observed that although bacteria could accelerate $\mathrm{Cd}$ transport, under certain conditions, $\mathrm{Cd}$ transport could be more retarded when $\mathrm{Cd}$ is adsorbed onto bacteria that had been retained by the porous media. Although the bacteria that were retained in the column may have been irreversibly retained, $\mathrm{Cd}$ could be desorbed from these bacteria as adsorption of
Cd was fully reversible onto both $B$. subtilis (Fowle and Fein, 2000) and E. coli (Yee and Fein, 2001). The fact that some bacteria were retained in the column is indicated by the results $k_{\text {att }}>0$ (Table 3 ) and concentration of a tracer in effluent from the column relative to its injection concentration $\left(c / c_{0}\right)<1$ in the bacterial BTCs (Fig. 6). The $R$ values for nonfacilitated Cd transport $(R=13-27)$ and bacteria-facilitated $\mathrm{Cd}$ transport $(R=$ $0.9-1.4)$ derived from this study are not significantly different from the field results: $R=7$ to 30 for nonfacilitated Cd transport and $R=0.7$ to 5.5 for bacteriafacilitated Cd transport, as reported by Pang and Close (1999a). The slightly greater variations in the field results are mainly because the aquifer media is more heterogeneous on a field scale than when it is packed into a column.

There was no significant change in $\beta$ and $\omega$ values between the ascending and descending limbs of the BTCs with bacteria-facilitated transport. This suggests that the residual bacteria retained in the column did not have a significant effect on the degree of non-equilibrium transport of $\mathrm{Cd}$ through the column. The $\beta$ values of 0.05 to 0.12 for nonfacilitated $\mathrm{Cd}$ transport suggest that only 5 to $12 \%$ of $\mathrm{Cd}$ adsorption was instantaneous and that the remaining 88 to $95 \%$ was kinetically limited. The non-equilibrium conditions for the nonfacilitated transport of $\mathrm{Cd}$ through the column are also reflected in the low values of the mass transfer coefficient, $\omega=1.24$ to 6.40 , and the fraction of exchange sites at equilibrium, $f \leq 0.10$ (Table 4 ). The above $\beta$ values derived from this study are slightly lower than the $\beta$ values of 0.20 to 0.41 derived from the field (Pang and Close, 1999a), but the $\omega$ values are similar between the studies (fieldderived values $\omega=1.82-3.33$ ). However, it should be noted that the above discussion excludes the case of bacteria-facilitated Cd transport (Step 2), for which $\beta=$ 1 and $f=1$, suggesting that all of the Cd adsorption 
sites were instantaneous and all of the exchange sites were at equilibrium.

Table 4 shows that, in general, the pore-water velocities associated with bacterial transport are greater than those associated with $\mathrm{Br}$ transport. This is consistent with the concept of size exclusion in colloid transport as described in the introduction. The faster transport of bacteria through alluvial gravel aquifers compared with conservative solutes has also been demonstrated in the studies of Sinton et al. (1997), Pang et al. (1998), and Sinton et al. (2000). Although the field data of Pang et al. (1998) and Sinton et al. (2000) showed that bacterial transport is less dispersive than solutes, a view also indicated by Johnson et al. (1995), this was not clearly shown in the present study. Possible explanations for this apparent discrepancy are that the bacterial data were noisy and that this variation reduced the accuracy of the dispersion results, and also that the duration of pulses was different for the bacteria and Br. An additional consideration is that the column was very short for nonretarded tracers, so their dispersion was limited.

As indicated in the Materials and Methods section, the flow velocity $(22 \mathrm{~m} / \mathrm{d})$ used in the column experiments is typical for coarse alluvial gravel aquifer. Similar ground water velocities are also seen in the field studies of Rossi et al. (1994) and Deborde et al. (1999) for gravel aquifers. This flow rate is much higher than those reported in the literature for sandy aquifers and even fine gravel aquifers (e.g., Cape Cod, MA), where ground water velocities are less than $1 \mathrm{~m} / \mathrm{d}$ (Pieper et al., 1997). In such slow flow rates, contaminant transport could be dominated by equilibrium processes. In contrast, $\mathrm{Cd}$ transport in coarse gravel media is dominated by nonequilibrium processes (Pang and Close, 1999a, 1999b, 1999c) because at fast flow rates, transport of $\mathrm{Cd}$ is comparatively faster than its kinetic adsorption reaction. Under non-equilibrium conditions, contaminant transport and hence parameter values would be affected by the flow velocity (Brusseau, 1992; Ptacek and Gillham, 1992; Maraqa et al., 1999; Pang et al., 2002). From our previous work (Pang et al., 2002), an increase in pore-water velocity led to an increase in both the partitioning coefficient $(\beta)$ and the first-order kinetic rate coefficient $(\alpha)$ and a decrease in the retardation factor $(R)$ and mass transfer coefficient $(\omega)$, but will have no apparent effect on the fraction of exchange sites at equilibrium $(f)$.

\section{CONCLUSIONS}

Our study has demonstrated that B. subtilis spores and $E$. coli cells act as carriers and facilitators for the transport of $\mathrm{Cd}$ in alluvial gravel aquifer media, resulting in a significant increase in total $\mathrm{Cd}$ concentrations and enhanced $\mathrm{Cd}$ travel velocity. When cotransported with the bacteria, transport of Cd was controlled by the bacteria and the effect of aquifer media became insignificant because the affinity of $\mathrm{Cd}$ to the bacteria is three orders of magnitude greater than its affinity to the aquifer media. Bacteria-facilitated transport of heavy metals may be a potential problem in sites such as landfills and during land disposal of industrial and domestic effluent and sludge, where bacteria and heavy metals might coexist. Toxic, immobile heavy metals, when cotransported with mobile bacteria, could arrive at water supplies much earlier than expected, and could, therefore, pose a threat to the quality of ground water.

Our experimental results suggest that there seems to be some threshold values in bacterial to metal concentrations for metal adsorption onto the bacteria and, consequently, bacteria-facilitated metal transport to occur. These threshold values may be specific to the experimental conditions involved as some factors (e.g., solution $\mathrm{pH}$, ionic strength, concentrations of bacteria and metals and their ratio) have major influence on the degree of metal adsorption onto bacteria. Nevertheless, the likelihood of bacteria-facilitated metal transport is probably greatest in areas that are close to contaminant sources where bacterial concentrations are high or where the concentration ratio of bacteria to metal is high. In natural ground water systems away from contaminant sources, the available surface area of aquifer media would be much greater than that of bacteria, so metal adsorption onto the aquifer media would dominate the transport of heavy metals.

Our study showed that $\mathrm{Cd}$ adsorption onto bacterial surfaces was positively related to solution $\mathrm{pH}$, bacterial concentration, and negative surface charge, was inversely related to metal concentration, and showed no clear relationship with bacterial size. Our study also suggests that the mechanism of $\mathrm{Cd}$ cotransport with $B$. subtilis spores clearly differs from that with $E$. coli, and adsorption of $\mathrm{Cd}$ onto the bacteria was a nonlinear kinetic process. As bacteria can mobilize heavy metals from porous media, it might be possible to develop bioremediation technology that can remove highly adsorbed heavy metals (such as lead, mercury, and arsenic) from contaminated sites by the introduction of certain bacteria. To achieve an optimal removal of heavy metals, some important factors (e.g., the type of bacteria, solution $\mathrm{pH}$, concentration ratio of bacteria to metal, and adsorption time) need to be considered in the design of the remediation regime.

\section{ACKNOWLEDGMENTS}

We acknowledge the staff at the Public Health Laboratory of the Institute of Environmental Science \& Research for providing and analyzing $E$. coli and other bacterial samples. We thank Dr. Chris Daughney of the Institute of Geological \& Nuclear Sciences Ltd. (New Zealand) for his valuable comments on the manuscript. This study was funded by the Foundation for Research, Science and Technology (New Zealand) under Contract no. CO3X0203.

\section{REFERENCES}

Alexander, M. 1977. Introduction to soil microbiology. John Wiley \& Sons, New York.

Artinger, R., T. Rabung, J.I. Kim, S. Sachs, K. Schmeide, K.H. Heise, G. Bernhard, and H. Nitsche. 2002. Humic colloid-borne migration of uranium in sand columns. J. Contam. Hydrol. 58:1-12.

Aylward, G.H., and T.J.V. Findlay. 1974. SI chemical data. 2nd ed. John Wiley \& Sons, New York.

Beveridge, T.J. 1999. Structures of gram-negative cell walls and their derived membrane vesicles. J. Bacteriol. 181:4725-4733.

Beveridge, T.J., and S.F. Koval. 1981. Binding of metals to cell envelopes of Escherichia coli K-12. Appl. Environ. Microbiol. 42: 325-335. 
Brusseau, M.L. 1992. Nonequilibrium transport of organic chemicals: The impact of pore-water velocity. J. Contam. Hydrol. 9:353-368.

Brusseau, M.L., T. Larsen, and T.H. Christensen. 1991. Rate-limited sorption and non-equilibrium transport of organic chemicals in low organic carbon aquifer materials. Water Resour. Res. 27: $1137-1145$

Cotoras, D., P. Viedma, L. Cifuentes, and A. Mestre. 1992. Sorption of metal ions by whole cells of Bacillus and Micrococcus. Environ. Technol. Lett. 13:551-559.

Daughney, C.J., and J.B. Fein. 1998. The effect of ionic strength on the adsorption of $\mathrm{H}^{+}, \mathrm{Cd}^{2+}, \mathrm{Pb}^{2+}$, and $\mathrm{Cu}^{2+}$ by Bacillus subtilis and Bacillus licheniformis: A surface complexation model. J. Colloid Interface Sci. 198:53-77.

Daughney, C.J., J.B. Fein, and N. Yee. 1998. A comparison of the thermodynamics of metal adsorption onto two common bacteria. Chem. Geol. 144:161-176.

Deborde, D.C., W.W. Woessner, Q.T. Kiley, and P. Ball. 1999. Rapid transport of viruses in a floodplain aquifer. Water Res. 33:2229-2238.

Donnelly, J.A., P.V. Scarpino, and D. Brunner. 1981. Recovery of fecal-indicator and pathogenic microbes from landfill leachate. p. 37-54. In D.W. Shultz (ed.) Land disposal: Municipal solid waste. Proc. of the 7th Annual Res. Symp., Philadelphia. 16-18 Mar. 1981. EPA Rep. EPA-600/9-81-002a. USEPA, Washington, DC

Fein, J.B., C.J. Daughney, N. Yee, and T.A. Davis. 1997. A chemical equilibrium model for metal adsorption onto bacterial surfaces. Geochim. Cosmochim. Acta 61:3319-3328.

Fein, J.B., and D. Delea. 1999. Experimental study of the effect of EDTA on Cd adsorption by Bacillus subtilis: A test of the chemical equilibrium approach. Chem. Geol. 161:375-383.

Fein, J.B., S. Scott, and N. Rivera. 2002. The effect of Fe on Si adsorption by Bacillus subtilis cell walls: Insights into non-metabolic bacterial precipitation of silicate minerals. Chem. Geol. 182: 265-273.

Fowle, D.A., and J.B. Fein. 1999. Competitive adsorption of metal cations onto two gram positive bacteria: Testing the chemical equilibrium model. Geochim. Cosmochim. Acta 63:3059-3067.

Fowle, D.A., and J.B. Fein. 2000. Experimental study of the reversibility of metal-bacteria adsorption reactions. Chem. Geol. 168:27-36.

Fowle, D.A., and J.B. Fein. 2001. Quantifying the effects of Bacillus subtilis cell walls on the precipitation of copper hydroxide from aqueous solution. Geomicrobiol. J. 18:77-91.

Ghiorse, W.C., and J.T. Wilson. 1988. Microbial ecology of the terrestrial subsurface. Adv. Appl. Microbiol. 33:107-172.

Harden, V., and J.O. Harris. 1952. The isoelectric point of bacterial cells. J. Bacteriol. 65:198-202.

Hornberger, G.M., A.L. Mills, and J.S. Herman. 1992. Bacterial transport in porous media: Evaluation of a model using laboratory observations. Water Resour. Res. 28:915-938.

Houston, J., M.A. Learner, and B.N. Dancer. 1989. Selection of an antibiotic-resistant strain of Bacillus subtilis var niger (B. globigii) for use as a tracer in microbially rich waters. Water Res. 23:387-388.

Johnson, W.P., K.A. Blue, B.E. Logan, and R.G. Arnold. 1995. Modelling bacterial detachment during transport through porous media as a residence-time-dependant process. Water Resour. Res. 31: 2649-2658.

Karathanasis, A.D. 1999. Subsurface migration of copper and zinc mediated by soil colloids. Soil Sci. Soc. Am. J. 63:830-838

Karathanasis, A.D. 2000. Colloid-mediated transport of $\mathrm{Pb}$ through soil porous media. Int. J. Environ. Stud. 57:579-596.

Kinoshita, T., R.C. Bales, M.T. Yahya, and C.P. Gerba. 1993. Bacteria transport in a porous medium: Retention of Bacillus and Pseudomonas on silica surfaces. Water Res. 27:1295-1301.

Konhauser, K.O., W.S. Fyfe, F.G. Ferris, and T.J. Beveridge. 1993. Metal sorption and mineral precipitation by bacteria in two Amazonian river systems: Rio Solimoes and Rio Negro, Brazil. Geology 21:1103-1106.

Kulczycki, E., F.G. Ferris, and D. Fortin. 2002. Impact of cell wall structure on the behaviour of bacterial cells and sorbents of cadmium and lead. Geomicrobiol. J. 19:553-565.

Maraqa, M.A., R.B. Wallace, and T.C. Voice. 1999. Effects of resi- dence time and degree of water saturation on sorption nonequilibrium parameters. J. Contam. Hydrol. 36:53-72.

Martinez, R.E., and F.G. Ferris. 2001. Chemical equilibrium modelling techniques for the analysis of high-resolution bacterial metal sorption data. J. Colloid Interface Sci. 243:73-80.

McCaulou, D.R., R.C. Bales, and J.F. McCarthy. 1994. Use of shortpulse experiments to study bacteria transport through porous media. J. Contam. Hydrol. 15:1-14.

Pang, L., and M.E. Close. 2001. A field tracer study of attenuation of atrazine, hexazinone and procymidone in a pumice sand aquifer. Pest Manage. Sci. 57:1142-1150.

Pang, L., and M.E. Close. 1999a. A field study of nonequilibrium and facilitated transport of $\mathrm{Cd}$ in an alluvial gravel aquifer. Ground Water 37:785-792.

Pang, L., and M.E. Close. 1999b. Nonequilibrium transport of Cd in alluvial gravels. J. Contam. Hydrol. 36:185-206.

Pang, L., and M.E. Close. 1999c. Field-scale physical nonequilibrium transport in an alluvial gravel aquifer. J. Contam. Hydrol. 38:447-464.

Pang, L., M. Close, M. Goltz, L. Sinton, H. Davies, C. Hall, and G. Stanton. 2003. Estimation of septic tank setback distances based on transport of E. coli and F-RNA phages. Environ. Int. 29:907-921.

Pang, L., M. Close, D. Schneider, and G. Stanton. 2002. Effect of pore-water velocity on chemical nonequilibrium transport of $\mathrm{Cd}$, $\mathrm{Zn}$, and $\mathrm{Pb}$ in alluvial gravel columns. J. Contam. Hydrol. 57: 241-259.

Pang, L., M.E. Close, and M. Noonan. 1998. Rhodamine WT and Bacillus subtilis transport through an alluvial gravel aquifer. Ground Water 36:112-122.

Park, N.-S., T.N. Blandford, and P.S. Huyakorn. 1991. VIRALT Version 2.0. A modular semi-analytical and numerical model for simulating viral transport in groundwater. Contract no. 68-C8-0003. HydroGeoLogic, Inc., prepared for USEPA, Washington, DC.

Pieper, A.P., J.N. Ryan, R.W. Harvey, G.L. Amy, T.H. Illangasekare, and D.W. Metge. 1997. Transport and recovery of bacteriophage PRD1 in a sand and gravel aquifer: Effect of sewage-derived organic matter. Environ. Sci. Technol. 31:1163-1170.

Pike, E.B., A.W.J. Bufton, and D.J. Gould. 1969. The use of Serratia indica and Bacillus subtilis var. niger spores for tracing sewage dispersion in the sea. J. Appl. Bacteriol. 32:206-216.

Rossi, P., A. De Carvalho-Dill, I. Müller, and M. Aragno. 1994. Comparative tracing experiments in a porous aquifer using bacteriophages and fluorescent dye on a test field located at Wilderwald (Switzerland) and simultaneously surveyed in detail on a local scale by radio-magneto-tellury (12-240 kHz). Environ. Geol. (Berlin) 23:192-200.

Ptacek, C.J., and R.W. Gillham. 1992. Laboratory and field measurements of non-equilibrium transport in the Borden aquifer, Ontario, Canada. J. Contam. Hydrol. 10:119-158.

Sinton, L.W., R.K. Finlay, L. Pang, and D.M. Scott. 1997. Transport of bacteria and bacteriophages in irrigated effluent into and through an alluvial gravel aquifer. Water Air Soil Pollut. 98:17-48.

Sinton, L.W., M.J. Noonan, R.K. Finlay, L. Pang, and M.E. Close. 2000. Transport and attenuation of bacteria and bacteriophage in an alluvial gravel aquifer. N. Z. J. Mar. Freshwater Res. 34:175-186.

Sneath, P.H.A., N.S. Mair, M.E. Sharpe, and J.G. Holt (ed.) 1986. Bergey's manual of systematic bacteriology. Vol. 2. Williams \& Wilkins, Baltimore.

Toride, N., F.J. Leij, and M.Th. Van Genuchten. 1995. The CXTFIT code for estimating transport parameters from laboratory or field. Version 2.0. USDA Res. Rep. 138. U.S. Salinity Lab., Riverside, CA.

Yee, N., and J.B. Fein. 2001. Cd adsorption onto bacteria: A universal adsorption edge? Geochim. Cosmochim. Acta 65:2037-2042.

Yee, N., and J.B. Fein. 2002. Does metal adsorption onto bacterial surfaces inhibit or enhance aqueous metal transport? Column and batch reactor experiments on Cd-Bacillus subtilis-quartz systems. Chem. Geol. 185:303-319.

Yee, N., J.B. Fein, and C.J. Daughney. 2000. Experimental study of the $\mathrm{pH}$, ionic strength, and reversibility behaviour of bacteriamineral adsorption. Geochim. Cosmochim. Acta 64:609-617. 